SILVA, GO; PEREIRA, AS; AZEVEDO, FQ; CARVVALHO, ADF; PINHEIRO, JB. 2019. Selection of Canadian potato clones for agronomic and frying quality traits. Horticultura Brasileira 37: 423-428. DOI - http://dx.doi.org/10.1590/S0102-053620190410

\title{
Selection of Canadian potato clones for agronomic and frying quality traits
}

\author{
Giovani Olegario da Silva ${ }^{1} \mathbb{D}$; Arione da S Pereira ${ }^{2} \mathbb{D}$; Fernanda Q Azevedo ${ }^{2} \mathbb{D}$; Agnaldo DF de Carvalho ${ }^{3} \mathbb{D}$; \\ Jadir B Pinheiro ${ }^{3 \mathbb{D}}$
}

'Embrapa Hortaliças, Canoinhas-SC, Brasil; giovani.olegario@embrapa.br; ${ }^{2}$ Embrapa Clima Temperado, Pelotas-RS, Brasil; arione.pereira@ embrapa.br; fernanda.azevedo@embrapa.br; ${ }^{3}$ Embrapa Hortaliças, Brasília-DF, Brasil; agnaldo.carvalho@embrapa.br; jadir.pinheiro@ embrapa.br

\begin{abstract}
The demand for cultivars suitable for processing, especially as frozen French fries, is increasing in Brazil. The Canadian expertise is high regarding the development of cultivars with processing characteristics; however, the growing conditions in Canada are quite different from those observed in Brazil. Thus, the aim of this work was to evaluate the performance of Canadian potato clones for their tuber yield, frying quality, plant vigor, and plant cycle, as potential new cultivars or to be used as a new source of variability for crosses. The experiments were conducted in Pelotas-RS and Canoinhas-SC, Brazil, in spring 2017. A set of 12 advanced Canadian potato clones from the Centre de Recherche Les Buissons, QB, Canada, were compared to three control cultivars used for processing. A randomized complete block design with three replicates, with two rows of 20 plants each per plot was used. Tuber yield, frying quality, plant vigor, and plant cycle traits were evaluated. Data were submitted to analysis of variance, grouping of means, and selection gains. It is possible to select genotypes with higher tuber yield and better frying quality, but it is difficult to add also a short cycle. In an attempt to select productive genotypes, with good frying quality, a not so long cycle, and vigor at least equivalent to the control cultivars, clones 15 and 16 were the best at both sites.
\end{abstract}

Keywords: Solanum tuberosum, tuber yield, frying color, specific gravity.

\section{RESUMO}

Seleção de clones canadenses de batata para caracteres agronômicos e de qualidade de fritura

A demanda por cultivares adequadas ao processamento industrial, principalmente na forma de palitos pré-fritos congelados, é crescente no Brasil. Sabe-se que a expertise canadense em relação ao desenvolvimento de cultivares com características de processamento é alta. No entanto, as condições de cultivo no Canadá são bastante diferentes das observadas no Brasil. Desta forma, o objetivo deste trabalho foi avaliar o desempenho de clones de batata de origem canadense para rendimento de tubérculos, qualidade de fritura, vigor e ciclo vegetativo, como potenciais novas cultivares ou para serem usadas como nova fonte de variabilidade em cruzamentos. Os experimentos foram realizados em Pelotas-RS e Canoinhas-SC, Brasil, na primavera 2017. Foi avaliado um conjunto de 12 clones pertencentes ao Centre de Recherche Les Buissons, QB, Canadá, em comparação com três cultivares testemunhas recomendadas para processamento na forma frita. $\mathrm{O}$ delineamento experimental foi blocos casualizados com três repetições e parcelas com duas linhas de 20 plantas. Foram avaliados caracteres de rendimento de tubérculos, qualidade de fritura, vigor e ciclo vegetativo das plantas. Os dados foram submetidos à análises de variância, de agrupamento de médias, e dos ganhos obtidos com a seleção. Verificou-se que é possível selecionar genótipos com maior rendimento de tubérculos e melhor qualidade de fritura, mas há dificuldade em associar também ciclo mais precoce. Na tentativa de selecionar genótipos produtivos, com boa qualidade de fritura, não muito tardios, e com vigor equivalente às cultivares testemunhas, verifica-se que os clones 15 e 16 foram superiores em ambos os locais.

Palavras-chave: Solanum tuberosum, rendimento de tubérculos, cor de fritura, peso específico.

\section{Received on April 5, 2019; accepted on October 28, 2019}

$\mathrm{T}_{\mathrm{t}}^{\mathrm{h}} \mathrm{d}$ he demand for cultivars suitable for processing, especially as frozen French fries, is increasing in Brazil. The Canadian expertise is high regarding the development of cultivars with processing characteristics; however, the growing conditions in Canada are quite different from those observed in Brazil in several aspects. The potato clones studied in this work were pre-selected in Quebec, Southeastern Canada, where cultivation is carried out in springsummer (May to September). In this period, the average photoperiod is between 16 and $18 \mathrm{~h}$, and temperatures are between six and $30^{\circ} \mathrm{C}$. On the other hand, potatoes are grown in two main cropping periods in southern Brazil, in spring and fall, to avoid very high temperatures in summer and frost in winter. The average photoperiod in the 
two cropping seasons is close to $12 \mathrm{~h}$, while temperatures vary between eight and $26^{\circ} \mathrm{C}$.

In response to the short photoperiod, the potato plant has a decreased plant cycle, early tuberization, and more competition for photoassimilates between plant growth and tuber filling. In addition, with lower light exposure, there is a lower photoassimilate production and, consequently, lower tuber yield (Pinto et al., 2010; Silva et al., 2012). Therefore, evaluations have to be carried out in Brazil in order to identify any superior material from the northern hemisphere.

Basically, potatoes can be marketed fresh or used for processing. Tuber appearance is of great importance for fresh market, while traits that confer frying quality are more important for processing, such as high specific gravity, low content of reducing sugars, and absence of physiological disorders (Souza et al., 2011). Specific gravity is an important trait because it is related to the dry mass content of tubers. High dry mass content results in higher processing yield and lower fat absorption during frying; it also influences texture and flavor of the final product (Schippers, 1976). A low content of reducing sugars prevents the browning of processed products, which compromises appearance and flavor (Stark \& Love, 2003). The demand for processed potato products is growing in Brazil, because of changes in eating habits, the need for semi-ready food, and the need for more uniform and practical products (Freitas et al., 2006). In addition, there is an increase in restaurant chains, which demand highquality semi-processed potatoes.

A potato clone destined for frying needs to have several traits, such as high tuber yield, in addition to processingrelated traits. It's also important to characterize the genotypes regarding plant development (vigor) and cycle. It is known that long-cycle cultivars $(>130$ days) are more productive than short-cycle cultivars ( $<100$ days) in temperate regions, probably because of the longer time in the field to synthesize and store photoassimilates; this trend is also verified in Brazilian conditions
(Silva \& Pinto, 2005; Rodrigues et al., 2009). On the other hand, farmers prefer short-cycle cultivars, as they allow for more crops per year in the same area and have a shorter exposure to the weather and lower risk of diseases and pests. In addition, they can provide an early harvest depending on the market price.

Plant vigor is another important trait. Silva et al. (2007), evaluating segregating potato families in the first field generation, verified positive correlations of medium magnitude between vigor and number and yield of tubers. Pereira et al. (2017), evaluating advanced potato clones, found direct medium to high positive correlations between vigor and total and marketable tuber yield, which indicates that more vigorous plants produce larger tubers, in greater numbers and with higher yield. However, in practice, this trait needs to be carefully selected, since clones with very vigorous plants usually also have a longer cycle (Bradshaw et al., 2004; Silva et al., 2007).

Thus, the aim of this work was to evaluate the performance of Canadian potato clones in their tuber yield, frying quality, plant vigor, and plant cycle, as potential new cultivars or to be used as a new source of variability for crosses.

\section{MATERIAL AND METHODS}

The experiments were conducted in Pelotas-RS $\left(31^{\circ} \mathrm{S}, 52^{\circ} \mathrm{W}, 50 \mathrm{~m}\right.$ altitude) and Canoinhas-SC $\left(26^{\circ} \mathrm{S}, 50^{\circ} \mathrm{W}\right.$ and 839 $\mathrm{m}$ altitude), in spring 2017.

A set of 12 advanced Canadian potato clones from the Centre de Recherche Les Buissons - CRLB, Quebec, Canada, were compared to Asterix, Atlantic, and BRSIPR Bel cultivars, which are used for frying.

In Pelotas, potatoes were planted on August 23, 2017, and in Canoinhas, on August 11, 2017. A randomized complete block design with three replicates, two rows of 20 plants each per plot, and spaced $75 \mathrm{~cm}$ between rows and $35 \mathrm{~cm}$ between plants was used. Seeds measured 40 to $50 \mathrm{~mm}$ in diameter, in the generation basic G1.

As fertilizer, $3 \mathrm{t} \mathrm{ha} \mathrm{a}^{-1}$ of NPK 04-14-
08 commercial formulation was applied in the furrows. Earthing up was carried out 30 days after planting, and the other cultural and phytosanitary treatments followed the recommendations of the regions (Pereira et al., 2010).

At 70 days after planting, which coincides with flowering of most clones, the experiment was evaluated for plant vigor using a scale from 1 to 9 for each plot ( $1=$ great vigor to $9=$ less vigor $)$, adapted from Pereira et al. (2017).

At 100 days after planting, immediately before harvest, the plant cycle of each plot was evaluated using a scale from 1 to $9(1=$ long cycle to $9=$ short cycle) from Silva et al. (2012).

Plants were harvested 100 days after planting at both sites, followed by grading tubers of each plot according to transverse diameter as marketable $(>45$ $\mathrm{mm}$ ) and non-marketable ( $\leq 45 \mathrm{~mm})$, counting and weighing, from which data were obtained on the following variables: Total mass of tubers $(\mathrm{kg} /$ plot); Mass of marketable tubers $(\mathrm{kg} /$ plot); Total number of tubers; Number of marketable tubers; Average mass of tubers $(\mathrm{g})$, obtained by dividing the total mass of tubers by the total number of tubers.

Specific gravity was evaluated in samples of marketable-sized tubers, using a hydrometer from Snack Food Association (Arlington, VA, EUA).

Frying color was evaluated using samples of three healthy and marketablesized tubers per plot. For this purpose, fifteen $2.0 \mathrm{~mm}$ thick slices were cut and fried in vegetable fat, at the initial temperature of $180^{\circ} \mathrm{C}$ until bubbling stopped. Frying color was evaluated with scores ranging from 1 to 9 ( $1=$ dark to $9=$ light), according to Silva $e t$ al. (2012).

Data of tuber mass were converted to $\mathrm{tha}^{-1}$ and data of number of tubers to ha/1000. Subsequently, the distribution of errors was verified using the Lilliefors test. Then, data were submitted to the individual and joint analysis of variance $(\mathrm{p}<0.05)$ and grouping of means using Scott-Knott test.

Gains obtained with the selection (GS) of the best genotypes in each site were calculated with the selection 
differential, or the difference between the means of the selected genotypes Xs subtracted from the value of the general mean Xo.

All statistical analyses were carried out using the computational application Genes (Cruz, 2016).

\section{RESULTS AND DISCUSSION}

The individual and joint analyses of variance showed significant differences for all traits $(\mathrm{p}<0.05)$ for differentiating the genotypes. There was also a significant genotype $\mathrm{x}$ environment interaction $(\mathrm{p}<0.05)$ for all traits, which indicates that the genotypes had different behavior in the tested environments for most traits (data not shown). In this way, the results are presented and discussed separately for each site.

The relation between genetic and environmental coefficient of variation $(\mathrm{CVg} / \mathrm{CV})$ was higher than $80 \%$ for all traits, except for plant vigor, number of marketable tubers, and frying color in Pelotas, which shows the great importance of genetic variation in relation to environmental variation, with a situation favorable to select mainly for the traits in which this relation was superior to the unit (Cruz et al., 2014). Phenotypic coefficients of variation were higher for the traits related to tuber yield and plant vigor. Mass and number of tubers are quantitative inherited traits and subject to greater environmental influence (Pereira et al., 2017). Plant vigor is also strongly influenced by environmental factors (Pereira et al., 2017), which may explain the lower experimental precision observed in this work.

The weather conditions were regular in Canoinhas, which favored tuber yield, with more tubers (37.43 tubers $\left./ \mathrm{m}^{2}\right)$ and higher average tuber mass $(98.82 \mathrm{~g} /$ tuber) (Table 1). The marketable tuber yield in this environment was $24.17 \mathrm{t}$ ha $^{-1}$, which is close to the mean yield of Santa Catarina $\left(23.70 \mathrm{t} \mathrm{ha}^{-1}\right)$. The mean yield of the experiment in Pelotas was low $\left(10.67 \mathrm{t} \mathrm{ha}^{-1}\right)$, but it was higher than the mean yield of the region $\left(6.62 \mathrm{tha}^{-1}\right)$ (IBGE, 2018).
Mean specific gravity at both sites was between 1.075 and 1.076 for Asterix, 1.086 for Atlantic, and 1.084 for BRSIPR Bel. These values were within the ranges observed by Pereira et al. (2015) for seven environments in the three southern states of Brazil, which were 1.083 (1.075 to 1.096), 1.092 (1.082 to 1.110), and 1.088 (1.075 to 1.093), for Asterix, Atlantic, and BRSIPR Bel, respectively. Therefore, the environments provided the appropriate expression of this trait.

In Canoinhas, clones 15, 16, 29, and 31 and the Atlantic control had the best performance in marketable tuber yield, which is the most important component trait of yield (Table 1). These clones presented mean marketable tuber yield of $33.43 \mathrm{t} \mathrm{ha}^{-1}$, which is $38.31 \%$ higher than the general mean for this site and $51.13 \%$ higher than the mean of the control cultivars. Clone 29 stood out with $41.12 \mathrm{t} \mathrm{ha}^{-1}$ of marketable tuber yield and $54.95 \mathrm{t} \mathrm{ha}^{-1}$ of total yield. Clones 6, 14, 29, 31, and 33, and the Atlantic control were the genotypes with the highest average tubers mass, i.e.,

Table 1. Agronomic and frying quality traits of 12 advanced clones and three potato cultivars evaluated in the spring crop 2017, in CanoinhasSC, Brasil. Canoinhas, Embrapa Hortaliças, 2019.

\begin{tabular}{|c|c|c|c|c|c|c|c|c|c|}
\hline Genotype & NCT & $\begin{array}{c}\text { MCT } \\
\left(\mathbf{t ~ h a}^{-1}\right) \\
\end{array}$ & TNT & $\begin{array}{c}\text { TMT } \\
\left(\mathbf{t ~ h a}^{-1}\right) \\
\end{array}$ & $\begin{array}{c}\mathbf{A T M} \\
\text { (g) } \\
\end{array}$ & SG & Color & Vigor & Cycle \\
\hline 4 & $108.89 \mathrm{c}$ & $15.51 \mathrm{~b}$ & $376.32 \mathrm{a}$ & $28.22 \mathrm{~b}$ & $73.10 \mathrm{~b}$ & $1.079 \mathrm{~b}$ & $7.00 \mathrm{a}$ & $2.50 \mathrm{~b}$ & $5.50 \mathrm{c}$ \\
\hline 6 & $127.92 \mathrm{c}$ & $23.98 \mathrm{~b}$ & $274.29 \mathrm{~b}$ & $33.20 \mathrm{~b}$ & 120.99 a & $1.085 \mathrm{a}$ & $7.00 \mathrm{a}$ & $3.00 \mathrm{a}$ & $2.00 \mathrm{~d}$ \\
\hline 13 & $116.98 \mathrm{c}$ & $18.27 \mathrm{~b}$ & $321.02 \mathrm{~b}$ & $29.36 \mathrm{~b}$ & $90.01 \mathrm{~b}$ & $1.072 \mathrm{c}$ & $6.50 \mathrm{~b}$ & $3.25 \mathrm{a}$ & $8.25 \mathrm{a}$ \\
\hline 14 & $157.84 \mathrm{c}$ & $23.52 \mathrm{~b}$ & $336.55 \mathrm{~b}$ & $34.98 \mathrm{~b}$ & $119.18 \mathrm{a}$ & $1.077 \mathrm{~b}$ & $6.00 \mathrm{~b}$ & $2.00 \mathrm{~b}$ & $7.25 \mathrm{~b}$ \\
\hline 15 & $182.41 \mathrm{~b}$ & $28.37 \mathrm{a}$ & $407.47 \mathrm{a}$ & $39.23 \mathrm{~b}$ & $96.85 \mathrm{~b}$ & $1.083 \mathrm{a}$ & $7.00 \mathrm{a}$ & $2.50 \mathrm{~b}$ & $6.00 \mathrm{c}$ \\
\hline 16 & $208.05 \mathrm{~b}$ & $33.80 \mathrm{a}$ & $517.82 \mathrm{a}$ & $49.18 \mathrm{a}$ & $94.45 \mathrm{~b}$ & $1.079 \mathrm{~b}$ & $7.50 \mathrm{a}$ & $2.00 \mathrm{~b}$ & $6.00 \mathrm{c}$ \\
\hline 19 & $139.62 \mathrm{c}$ & $22.77 \mathrm{~b}$ & $319.10 \mathrm{~b}$ & $31.49 \mathrm{~b}$ & $98.90 \mathrm{~b}$ & $1.078 \mathrm{~b}$ & $6.00 \mathrm{~b}$ & $3.25 \mathrm{a}$ & $7.25 \mathrm{~b}$ \\
\hline 24 & $87.04 \mathrm{c}$ & $11.86 \mathrm{~b}$ & $462.53 \mathrm{a}$ & $28.25 \mathrm{~b}$ & $61.45 \mathrm{~b}$ & $1.084 \mathrm{a}$ & $7.00 \mathrm{a}$ & $2.00 \mathrm{~b}$ & $8.25 \mathrm{a}$ \\
\hline 27 & $176.67 \mathrm{~b}$ & $25.11 \mathrm{~b}$ & $411.11 \mathrm{a}$ & $39.39 \mathrm{~b}$ & $97.84 \mathrm{~b}$ & $1.085 \mathrm{a}$ & $7.50 \mathrm{a}$ & $1.50 \mathrm{~b}$ & $5.75 \mathrm{c}$ \\
\hline 29 & $258.21 \mathrm{a}$ & $41.12 \mathrm{a}$ & $484.71 \mathrm{a}$ & $54.95 \mathrm{a}$ & $112.20 \mathrm{a}$ & $1.080 \mathrm{~b}$ & $6.50 \mathrm{~b}$ & $1.25 \mathrm{~b}$ & $2.75 \mathrm{~d}$ \\
\hline 31 & $181.04 \mathrm{~b}$ & $30.46 \mathrm{a}$ & $353.87 \mathrm{~b}$ & $39.90 \mathrm{~b}$ & $113.41 \mathrm{a}$ & $1.074 \mathrm{c}$ & $7.00 \mathrm{a}$ & $3.00 \mathrm{a}$ & $6.50 \mathrm{c}$ \\
\hline 33 & $124.82 \mathrm{c}$ & $21.35 \mathrm{~b}$ & $224.86 \mathrm{~b}$ & $27.18 \mathrm{~b}$ & $119.75 \mathrm{a}$ & $1.083 \mathrm{a}$ & $5.50 \mathrm{c}$ & $4.00 \mathrm{a}$ & $7.25 \mathrm{~b}$ \\
\hline Atlantic & $174.51 \mathrm{~b}$ & $29.46 \mathrm{a}$ & $295.50 \mathrm{~b}$ & $36.43 \mathrm{~b}$ & $123.25 \mathrm{a}$ & $1.083 \mathrm{a}$ & $7.50 \mathrm{a}$ & $2.00 \mathrm{~b}$ & $9.00 \mathrm{a}$ \\
\hline Asterix & $124.50 \mathrm{c}$ & $19.73 \mathrm{~b}$ & $411.30 \mathrm{a}$ & $33.36 \mathrm{~b}$ & $81.47 \mathrm{~b}$ & $1.076 \mathrm{~b}$ & $5.50 \mathrm{c}$ & $2.25 \mathrm{~b}$ & $7.00 \mathrm{~b}$ \\
\hline BRSIPR Bel & $148.77 \mathrm{c}$ & $17.18 \mathrm{~b}$ & $417.99 \mathrm{a}$ & $33.01 \mathrm{~b}$ & $79.51 \mathrm{~b}$ & $1.081 \mathrm{a}$ & $7.50 \mathrm{a}$ & $3.00 \mathrm{a}$ & $7.50 \mathrm{~b}$ \\
\hline
\end{tabular}

$\mathrm{NCT}=$ number of marketable tubers $\left(\mathrm{ha}^{-1} / 1000\right) ; \mathrm{MCT}=$ mass of marketable tubers $\left(\mathrm{t} \mathrm{ha} \mathrm{a}^{-1}\right) ; \mathrm{TNT}=$ total number of tubers $\left(\mathrm{ha}^{-1} / 1000\right)$; $\mathrm{TMT}=$ total mass of tubers $\left(\mathrm{t} \mathrm{ha}^{-1}\right) ; \mathrm{ATM}=$ average tuber mass $\left(\mathrm{g} \mathrm{tuber}^{-1}\right) ; \mathrm{SG}=$ specific gravity; Color= frying color (score from $1=$ dark to $9=$ light); Vigor= plant vigor (score from $1=$ great vigor to $9=$ less vigor); Cycle=: plant cycle (score from $1=$ long to $9=$ short). Means followed by same letters in the column belong to the same group by Scott-Knott test, $5 \%$ probability. 
Table 2. Agronomic and frying quality traits of 12 advanced clones and three potato cultivars evaluated in the spring crop 2017, in PelotasRS, Brasil. Canoinhas, Embrapa Hortaliças, 2019.

\begin{tabular}{lrrrrrrrr}
\hline Genotype & NCT & $\begin{array}{c}\text { MCT } \\
\left(\mathbf{t ~ h a}^{-1}\right)\end{array}$ & TNT & $\begin{array}{c}\text { TMT } \\
\left(\mathbf{t ~ h a} \mathbf{~}^{-1}\right)\end{array}$ & $\begin{array}{c}\text { ATM } \\
(\mathbf{g})\end{array}$ & $\mathbf{S G}$ & Color & Vigor \\
\hline 4 & $147.78 \mathrm{a}$ & $11.07 \mathrm{a}$ & $320.00 \mathrm{a}$ & $16.19 \mathrm{a}$ & $49.98 \mathrm{c}$ & $1.078 \mathrm{~b}$ & $7.00 \mathrm{a}$ & $3.00 \mathrm{a}$ \\
6 & $156.67 \mathrm{a}$ & $15.52 \mathrm{a}$ & $267.22 \mathrm{~b}$ & $19.38 \mathrm{a}$ & $72.11 \mathrm{~b}$ & $1.084 \mathrm{a}$ & $7.50 \mathrm{a}$ & $2.50 \mathrm{~b}$ \\
13 & $148.05 \mathrm{a}$ & $11.32 \mathrm{a}$ & $379.17 \mathrm{a}$ & $17.83 \mathrm{a}$ & $47.31 \mathrm{c}$ & $1.069 \mathrm{c}$ & $5.25 \mathrm{~b}$ & $3.00 \mathrm{a}$ \\
14 & $64.39 \mathrm{~b}$ & $5.21 \mathrm{~b}$ & $146.61 \mathrm{c}$ & $7.48 \mathrm{c}$ & $49.33 \mathrm{c}$ & $1.081 \mathrm{~b}$ & $5.50 \mathrm{~b}$ & $3.75 \mathrm{a}$ \\
15 & $119.72 \mathrm{~b}$ & $11.03 \mathrm{a}$ & $251.95 \mathrm{~b}$ & $15.00 \mathrm{~b}$ & $58.91 \mathrm{~b}$ & $1.078 \mathrm{~b}$ & $5.75 \mathrm{~b}$ & $2.25 \mathrm{~b}$ \\
16 & $153.33 \mathrm{a}$ & $11.98 \mathrm{a}$ & $391.11 \mathrm{a}$ & $19.33 \mathrm{a}$ & $48.68 \mathrm{c}$ & $1.077 \mathrm{~b}$ & $6.50 \mathrm{a}$ & $2.25 \mathrm{~b}$ \\
19 & $136.67 \mathrm{a}$ & $12.43 \mathrm{a}$ & $278.34 \mathrm{~b}$ & $17.52 \mathrm{a}$ & $62.61 \mathrm{~b}$ & $1.078 \mathrm{~b}$ & $6.50 \mathrm{a}$ & $3.00 \mathrm{a}$ \\
24 & $98.33 \mathrm{~b}$ & $6.70 \mathrm{~b}$ & $351.67 \mathrm{a}$ & $14.12 \mathrm{~b}$ & $41.00 \mathrm{c}$ & $1.082 \mathrm{a}$ & $6.75 \mathrm{a}$ & $3.25 \mathrm{a}$ \\
27 & $113.00 \mathrm{~b}$ & $9.14 \mathrm{~b}$ & $268.55 \mathrm{~b}$ & $13.52 \mathrm{~b}$ & $48.38 \mathrm{c}$ & $1.081 \mathrm{~b}$ & $5.00 \mathrm{~b}$ & $3.00 \mathrm{a}$ \\
29 & $105.00 \mathrm{~b}$ & $9.03 \mathrm{~b}$ & $218.33 \mathrm{c}$ & $12.45 \mathrm{~b}$ & $57.27 \mathrm{~b}$ & $1.080 \mathrm{~b}$ & $5.50 \mathrm{~b}$ & $3.00 \mathrm{a}$ \\
31 & $114.72 \mathrm{~b}$ & $10.11 \mathrm{a}$ & $263.61 \mathrm{~b}$ & $14.62 \mathrm{~b}$ & $57.74 \mathrm{~b}$ & $1.081 \mathrm{~b}$ & $6.00 \mathrm{~b}$ & $3.00 \mathrm{a}$ \\
33 & $83.89 \mathrm{~b}$ & $7.71 \mathrm{~b}$ & $182.78 \mathrm{c}$ & $11.44 \mathrm{~b}$ & $62.64 \mathrm{~b}$ & $1.067 \mathrm{c}$ & $5.25 \mathrm{~b}$ & $3.00 \mathrm{a}$ \\
Atlantic & $168.05 \mathrm{a}$ & $15.61 \mathrm{a}$ & $296.95 \mathrm{~b}$ & $19.47 \mathrm{a}$ & $65.00 \mathrm{~b}$ & $1.088 \mathrm{a}$ & $7.75 \mathrm{a}$ & $2.50 \mathrm{~b}$ \\
Asterix & $103.89 \mathrm{~b}$ & $9.09 \mathrm{~b}$ & $220.00 \mathrm{c}$ & $20.72 \mathrm{a}$ & $98.62 \mathrm{a}$ & $1.075 \mathrm{~b}$ & $5.25 \mathrm{~b}$ & $2.50 \mathrm{~b}$ \\
BRSIPR Bel & $184.45 \mathrm{a}$ & $14.13 \mathrm{a}$ & $381.11 \mathrm{a}$ & $20.33 \mathrm{a}$ & $52.76 \mathrm{c}$ & $1.086 \mathrm{a}$ & $7.50 \mathrm{a}$ & $2.25 \mathrm{~b}$ \\
\hline
\end{tabular}

$\mathrm{NCT}=$ number of marketable tubers $\left(\mathrm{ha}^{-1} / 1000\right) ; \mathrm{MCT}=$ mass of marketable tubers $\left(\mathrm{t} \mathrm{ha}^{-1}\right)$; $\mathrm{TNT}=$ total number of tubers $\left(\mathrm{ha}^{-1} / 1000\right) ; \mathrm{TMT}=$ total mass of tubers $\left(\mathrm{t} \mathrm{ha}^{-1}\right)$; ATM= average tuber mass $\left(\mathrm{g} \mathrm{tuber}^{-1}\right)$; $\mathrm{SG}=$ specific gravity; Color= frying color ( light); Vigor= plant vigor (score from $1=$ great vigor to $9=$ less vigor). Means followed by same letters in the column belong to the same group by Scott-Knott test, $5 \%$ probability.

presenting larger tubers, ranging from 112.20 to $123.25 \mathrm{~g}$.

Regarding frying quality traits, clones $6,15,24$, and 27 showed similar performance for specific gravity and frying color when compared to the BRSIPR Bel and Atlantic controls. These cultivars are recommended for processing as 'chips'. Only clones 13 and 31 presented inferior performance compared to the Asterix control, which is used in large scale in the industry of French fries in Brazil (Table 1).

Therefore, for Canoinhas, mainly clone 15, but also clones 16, 29 and Atlantic control were superior when higher marketable tuber yield and better frying quality are combined (Table 1). On average, these clones showed marketable tuber yield 50\% higher than the experiment mean, which is an increase from 1.080 to 1.081 for specific gravity and improvement of the frying color from 6.73 to 7.12 . Regarding specific gravity, industries prefer tubers with high dry matter content, of at least $20 \%$ in general (Araújo et al., 2016), which is equivalent to the specific gravity of 1.078 .

In relation to plant traits, vigor, and cycle, in Canoinhas, clones 6, 13, 19, 31 , and 33 and the BRSIPR Bel control presented less vigorous plants, while clones 13, 14, 19, 24, and 33 were earlier, similar to the three controls, while clones 6 and 29 were the latest ones (Table 1). Therefore, three of the five early and least vigorous clones were coincident, which supports the relation between these traits observed by Bradshaw et al. (2004) and Silva et al. (2007).

In Pelotas, clones 4, 6, 13, 15, 16, 19, 31 and the Atlantic and BRSIPR Bel controls presented the highest marketable tuber yield, which was $12.58 \mathrm{t} \mathrm{ha}^{-1}$ on average, that is, $17.90 \%$ more than the general mean of this environment (Table 2). Among these clones, almost all were grouped together with controls, with the highest total tuber yields, except clones 15 and 31 . Clones 6, 15, 19, 31, 29, and $33 \mathrm{had}$ an average mass of marketable tubers that was similar to the Atlantic and Asterix controls.
Regarding the frying quality traits, together with specific gravity and frying color, clones 6 and 24 were the best ones when compared to Atlantic and BRSIPR Bel controls (Table 2).

In addition, only clones 13 and 33 were inferior to Asterix. For plant vigor, clones 6,15 , and 16 were as vigorous as the three control cultivars. The other clones presented less vigorous plants.

For Pelotas, considering tuber yield and frying quality, clone 6 was the best one, with performance equivalent to the Atlantic and BRSIPR Bel controls. However, when using the frying quality of the Asterix control as a cut-off point, clones $4,15,16,19$, and 31 also stand out. Although all clones showed plant vigor similar to the controls or even less vigorous plants, a trend of more vigorous plants in these clones can be observed. Thus, the best genotypes were clones $6,19,4,31,16$, and 15 , and Atlantic and BRSIPR Bel controls when the grouping of means is considered.

Therefore, clones 15 and 16 have higher yield potentials and better frying quality, shorter cycles, and similar vigor 
Table 3. Estimates of gains with the selection of genotypes Atlantic, 15 and 16 in CanoinhasSC, Brasil, and genotypes Atlantic, 15, 16, 6, 19, 4, 31 and BRSIPR Bel in Pelotas-RS, Brasil, for agronomic and frying quality traits of 12 advanced clones and three potato cultivars evaluated in the spring crop 2017. Canoinhas, Embrapa Hortaliças, 2019.

\begin{tabular}{|c|c|c|c|c|}
\hline & Xo & $\mathrm{Xs}$ & SD & GS (\%) \\
\hline & \multicolumn{4}{|c|}{ Canoinhas } \\
\hline $\mathrm{NCT}$ & 154.48 & 188.32 & 33.84 & 21.91 \\
\hline $\operatorname{MCT}\left(\mathrm{t} \mathrm{ha}^{-1}\right)$ & 24.17 & 30.54 & 6.37 & 26.35 \\
\hline TNT & 374.29 & 406.93 & 32.64 & 8.72 \\
\hline TMT $\left(\mathrm{t} \mathrm{ha}^{-1}\right)$ & 35.87 & 41.61 & 5.74 & 16.00 \\
\hline $\operatorname{ATM}(\mathrm{g})$ & 98.82 & 104.85 & 6.03 & 6.10 \\
\hline SG & 1.08 & 1.082 & 0.02 & 1.85 \\
\hline Color & 6.73 & 7.330 & 0.60 & 8.92 \\
\hline Vigor & 2.50 & 2.170 & -0.33 & -13.20 \\
\hline Cycle & 6.42 & 7.000 & 0.58 & 9.03 \\
\hline \multirow[t]{2}{*}{ Selected } & \multicolumn{4}{|c|}{ Atlantic, 15,16} \\
\hline & \multicolumn{4}{|c|}{ Pelotas } \\
\hline NCT & 126.53 & 147.67 & 21.14 & 16.71 \\
\hline $\operatorname{MCT}\left(\mathrm{t} \mathrm{ha}^{-1}\right)$ & 10.67 & 12.74 & 2.07 & 19.40 \\
\hline TNT & 281.16 & 306.29 & 25.13 & 8.94 \\
\hline TMT $\left(\mathrm{t} \mathrm{ha}^{-1}\right)$ & 15.96 & 17.73 & 1.77 & 11.09 \\
\hline $\operatorname{ATM}(\mathrm{g})$ & 58.15 & 58.47 & 0.32 & 0.55 \\
\hline SG & 1.079 & 1.081 & 0.02 & 1.85 \\
\hline Color & 6.20 & 6.81 & 0.61 & 9.84 \\
\hline Vigor & 2.82 & 2.59 & -0.23 & -8.16 \\
\hline
\end{tabular}

Selected Atlantic, 15, 16, 6, 19, 4, 31, BRSIPR Bel

$\mathrm{NCT}=$ number of marketable tubers $\left(\mathrm{ha}^{-1} / 1000\right) ; \mathrm{MCT}=$ mass of marketable tubers $\left(\mathrm{t} \mathrm{ha}^{-1}\right)$; $\mathrm{TNT}=$ total number of tubers $\left(\mathrm{ha}^{-1} / 1000\right) ; \mathrm{TMT}=$ total mass of tubers $\left(\mathrm{tha}^{-1}\right)$; ATM $=$ average tuber mass $\left(\mathrm{g}\right.$ tuber $\left.^{-1}\right) ; \mathrm{SG}=$ specific gravity; Color $=$ frying color (score from $1=$ dark to $9=$ light); Vigor $=$ plant vigor (score from $1=$ great vigor to $9=$ less vigor); $\mathrm{Cycle}=$ plant cycle (score from $1=$ long to $9=$ short); $\mathrm{Xo}=$ overall mean; $\mathrm{Xs}=$ mean of selected genotypes; $\mathrm{SD}=$ selection differential; GS $(\%)=$ gain with selection.

to the Atlantic, BRSIPR Bel, and Asterix controls at both sites. In Pelotas, clones $6,19,4$, and 31 also presented good performance.

The selection of these eight clones for Pelotas, and the clones 15, 16 and Atlantic control, that presented good yield, good frying quality, vigor equivalent to the control cultivars and not so long vegetative cycle in Canoinhas, resulted in gains of 19.40 and $26.35 \%$ of marketable tuber yield in Pelotas and Canoinhas, respectively. Gains were also present when these genotypes were considered for other yield traits, as well as frying quality, mainly for color, which was between
9.84 and $8.92 \%$. This would also allow a gain of $9.03 \%$ in plant cycle in Canoinhas. The plants would be 8.16 to $13.20 \%$ more vigorous on average than the mean of the experiments, which would not be a problem, since no clone was more vigorous than the controls in this study (Table 3).

So, we verified that it is possible to select genotypes with higher tuber yield and better frying quality, but it is difficult to add a short cycle. To select productive genotypes, with good frying quality, a not so long cycle, and vigor at least equivalent to the control cultivars, the clones 15 and 16 were among the best at both sites.

\section{REFERENCES}

ARAÚJO, TH; PÁDUA, JG; SPOTO, MHF; ORTIZ, VDG; MARGOSSIAN, PL; DIAS, CTS; MELO, PCT. 2016. Productivity and quality of potato cultivars for processing as shoestrings and chips. Horticultura Brasileira 34: 554-560

BRADSHAW, JE; PANDE, B; BRYAN, GJ; HACKETT, CA; MCLEAN, K; STEWART, HE. 2004. Interval mapping of quantitative trait loci for resistance to late blight [Phytophthora infestans (Mont.) de Bary]; height; maturity in a tetraploid population of potato (Solanum tuberosum subsp. tuberosum). Genetics 168: 983-995.

CRUZ, CD. 2016. Genes software-extended; integrated with the R; Matlab; Selegen. Acta Scientiarum Agronomy 38: 547-552.

CRUZ, CD; REGAZZI, AJ; CARNEIRO, PCS. 2014. Modelos biométricos aplicados ao melhoramento genético. v. 2; 3.ed. Viçosa: UFV. 668p.

FREITAS, ST; BISOGNIN, DA; GÓMEZA, CS; SAUTTER, CK; COSTA, LC; RAMPELOTTO, MV. 2006. Qualidade para processamento de clones de batata cultivados durante a primavera e outono no Rio Grande do Sul. Ciência Rural 36: 80-85.

IBGE - Instituto Brasileiro de Geografia e Estatística. 2017. Produção agrícola municipal 2015: informações sobre culturas temporárias. Rio de Janeiro: IBGE. Available at $<\mathrm{http}$ // www.sidra.ibge.gov.br/bda/pesquisas/pam/ default.asp>. Accessed February 16; 2018.

PEREIRA, AS. (org). 2010. Produção de batata no Rio Grande do Sul. Sistema de produção, 19. Pelotas: Embrapa Clima Temperado. 95p.

PEREIRA, AS; NAZARENO, NRX; SILVA, GO; BERTONCINI, O; CASTRO, CM; HIRANO, E; BORTOLETTO, AC; TREPTOW, RO; DUTRA, LF; LIMA, MF; GOMES, CB; KROLOW, ACR; MEDEIROS, CAB; CASTRO, LAS; SUINAGA, FA; LOPES, CA; MELO, PE. 2015. BRSIPR Bel: Cultivar de batata para chips com tubérculos de boa aparência. Horticultura Brasileira 33: 135139.

PEREIRA, AS; SILVA, GO; CARVALHO, ADF; PONIJALEKI, RS. 2017. Performance of advanced potato clones: plant vigor; tuber yield; specific gravity. Horticultura Brasileira 35: 440-444.

PINTO, CABP; TEIXEIRA, AL; NEDER, DG; ARAÚJO, RR; SOARES, ARO; RIBEIRO, GHMR; LEPRE, AL. 2010. Potencial de clones elite de batata como novas cultivares para Minas Gerais. Horticultura Brasileira 28: 399-405.

RODRIGUES, GB; PINTO, CAB; BENITES, FRG; MELO, DS. 2009. Seleção para duração do ciclo vegetativo em batata e relação com a produtividade de tubérculos. Horticultura Brasileira 27: 280-285.

SCHIPPERS, PA. 1976. The relationship between specific gravity; percentage of dry matter in potato tubers. American Potato Journal 53: 
111-122.

SILVA, LAS; PINTO, CABP. 2005. Duration of the growth cycle; the yield potential of potato genotypes. Crop Breeding and Applied Biotechnology 5: 20-28.

SILVA, GO; PEREIRA, AS; SOUZA, VQ; CARVALHO, FIF; FRITSCHE NETO, R. 2007. Correlações entre caracteres de aparência e rendimento e análise de trilha para aparência de batata. Bragantia 66: 381-388.

SILVA, GO; CASTRO, CM; TERRES, LR; ROHR, A; SUINAGA, FA; PEREIRA, AS. 2012. Desempenho agronômico de clones elite de batata. Horticultura Brasileira 30: 557-560. SOUZA, ZS; BISOGNIN, DA; JUNIOR, GRM; GNOCATO, FS. 2011. Seleção de clones de batata para processamento industrial em condições de clima subtropical e temperado. Pesquisa Agropecuária Brasileira 46: 15031512.

STARK, JC; LOVE, SL. 2003. Tuber quality. In: STARK, JC; LOVE, SL (eds). Potato production systems. Aberdeen: University of Idaho 16: 329-343. 